\title{
The role of epiphytic populations in pathogenesis of the genus Xanthomonas bacteria
}

\author{
Elena I. Kyrova ${ }^{1}$, Fevzi S. Dzhalilov, ${ }^{2, *}$, and Alexander N. Ignatov ${ }^{3,4}$ \\ ${ }^{1}$ Russian Research Institute of Plant Protection, Plant Immunity to Diseases Laboratory, 196608 Saint \\ Petersburg, Russia \\ ${ }^{2}$ Russian State Agrarian University - Moscow Timiryazev Agricultural Academy, Department of \\ Plant Protection, 127550 Moscow, Russia \\ ${ }^{3}$ Russian University of People's Friendship, Agrarian and Technological Institute, Department of \\ Agrobiotechnology, 117198 Moscow, Russia \\ ${ }^{4}$ PhytoEngineering R\&D Center, LLC, 141880 Rogachevo, Russia
}

\begin{abstract}
Global climate warming and involvement of new regions with endemic populations of microorganisms in commercial seed production have led to an increase in the diversity of phytopathogenic bacteria that are affecting major crops, including the fruit trees. As a rule, emergence of new pathogens is associated with importation of infected seeds and planting material, cultivation of new species and varieties of plants, and expansion of agricultural trade with foreign countries. One of the leaders in diversity among phytopathogens is the genus Xanthomonas bacteria, affecting more than 400 plant species. Among the characteristic signs of xanthomonads is the high frequency of horizontal gene transfer both within the genus and between phylogenetically removed bacterial taxa - up to $25 \%$ of the genes are of this origin. In this paper, we consider another source of increasing the number of phytopathogenic species - by the epiphytic populations. These bacteria are the likely ancestral form of the phytopathogenic bacteria of the genus Xanthomonas.
\end{abstract}

\section{Introduction}

Representatives of the genus Xanthomonas are the widespread phytopathogens that cause diseases of 70 genera of monocotyledonous and 170 genera of dicotyledonous plants. The host range of each Xanthomonas group is in most cases limited to several species or related genera of the same plant family [1]. However, this genus includes not only pathogenic strains of bacteria. Isolates of $X$. campestris that do not cause disease symptoms were found in epiphytic populations of various plants [2], avirulent or slightly pathogenic xanthomonads were isolated from cabbage [3], legumes [4], apple trees [2], tomatoes and peppers [5], and rice [6]. In addition, genetic studies of xanthomonads revealed the presence of a group of avirulent strains belonging to the species $X$. arboricola [7]. Most of the isolated nonpathogenic strains belong to $X$. arboricola and cluster separately from typical pathogenic

\footnotetext{
*Corresponding author: labzara@mail.ru
} 
bacteria [8-9]. Pathogenic and non-pathogenic strains are likely to exist together. Possibly, epiphytic and pathogenic strains can compete with each other, which, according to some research data, could be used as biocontrol [9].

\section{Materials and methods}

\subsection{Strains}

32 strains of $X$. arboricola isolated from tomato, rapeseed, sunflower, barley and cabbage in the Central Chernozemic economic region, the Krasnodar Krai and Stavropol Krai, the Rostov, Saratov and Moscow Oblasts, the republics of Adygea and North Ossetia-Alania in 2009-2018 were used in this work.

\subsection{Cultivation of strains and infection of host plants}

The strains were cultured on YDC media (glucose $-10.0 \mathrm{~g}$; yeast extract $-10.0 \mathrm{~g} ; \mathrm{CaCO}_{3}-$ $20.0 \mathrm{~g}$; agar - $18.0 \mathrm{~g}$ per $1 \mathrm{l}$ ) and SQ media (succinic acid - $10.0 \mathrm{~g}$, quinic acid $-5.0 \mathrm{~g}$, $\mathrm{K}_{2} \mathrm{HPO}_{4}-1.5 \mathrm{~g},\left(\mathrm{NH}_{4}\right)_{2} \mathrm{SO}_{4}-1.0 \mathrm{~g}$, yeast extract $-0.5 \mathrm{~g}$ per 1 1). Assessment of the pathogenicity of the strains was carried out by cutting the leaves with scissors that were moistened in a bacterial suspension $\left(10^{8} \mathrm{CFU} / \mathrm{ml}\right)$. The suspension was obtained by washing 48-hours long bacteria culture grown on YDC medium at $28{ }^{\circ} \mathrm{C}$. Observation of the disease development was carried out daily, the symptoms were recorded 21 and 30 days after infection.

\subsection{Determination of species and genetic traits}

The species affiliation of the strains was previously determined by the sequence of $16 \mathrm{~S}$ rRNA and species-specific PCR amplification [10]. The analysis of the spectrum of genes of the type III secretion system (T3SS) and T3SS effectors (T3E) was performed by PCR amplification with primers to conserved regions of the corresponding genes [11-12]. Fragments of 7 genes were used for multilocus sequence typing (MLST): gyrB, dnaK, rpoD, purA, $n r d B, \operatorname{prp} C, f a b B$. Amplification was performed according to previously published protocols [13-14]. The genome of the bacterium $X$. arboricola str. 3004 (NCBI AZQY00000000) was sequenced on the Roche GS FLX platform [15].

\subsection{Comparative genomics}

Comparative genome analysis was carried out using Function based comparison and Sequence based comparison algorithms implemented on the RAST server [16], as well as the Progressive mauve algorithm - the multiple genome alignment with gene gain, loss and rearrangement [17]. 


\section{Results and discussion}

\subsection{Results}

\subsubsection{Infection of plants}

All 32 studied strains were virulent for at least one tested host plant. The oblong watery spots of light green color appeared on the cereal leaves 14-21 days after inoculation, then they acquired a yellow-brown color. The leaves died after severe damage. Pathogens caused leaf blight, leaf and stem spots in sunflower. Oilseed rape had the following symptoms: wilting, the V-shaped yellowing and necrosis of the tissues of the affected leaves between the leaf veins, as well as the darkening of the stem vessels. Walnut seedlings had the following symptoms: leaf blight, wilting of shoots and death of plants within a month after infection.

\subsubsection{Genetic analysis}

PCR analysis has not revealed T3SS genes and associated T3E genes among 32 studied strains of the tested phytopathogenic bacteria. MLST confirmed the identification of all bacteria as $X$. arboricola, but did not allow to refer the studied strains to any of the known pathovariants of this species. At least one or more of the studied genes in the MLST were closer to $X$. campestris, $X$. oryzae, or $X$. vesicatoria than to $X$. arboricola. Diversity of these polymorphic genes was explained more by the process of parallel adaptive evolution, than by interspecies horizontal transfer of the household genes that were used for MLST.

\subsubsection{Genome annotation and analysis}

The genome of strain 3004, typical of the entire group, was annotated on the RAST server. A total of 4230 coding sequences were identified. GC composition of the genome is $66 \%$, which is within the standard range for bacteria of the species $X$. arboricola. When annotating the genome, phage sequences of Xantho Xp10 NC 004902 were detected. Phage sequences flank the VirE protein gene (COG5545). Gene sequences were allegedly obtained from Xylella fastidiosa 9a5c. Therefore, the fact of horizontal transfer of the virulence factor is assumed. A detailed study of the genes of the membrane transport system confirmed the absence of T3SS genes and associated effector protein genes. The presence of a fully functional type IV secretion system was revealed. The type IV secretion system of strain 3004 is represented by 10 virB genes, the virD4 gene, and 23 genes responsible for the synthesis and assembly of pili for the secretion of Vir proteins. The presence of the virD4 gene is the key for protein secretion via T4SS, and the presence of $\operatorname{vir} B 8, \operatorname{vir} B 9$, virB10, and virB11 is essential for T4SS Xanthomonas as a whole [18].

\subsubsection{Comparative genomics}

Reconstruction of metabolic models and comparison of nucleotide sequences of the genome of strain $X$. arboricola 3004 with sequences of the reference genome (X. arboricola pv. Juglandis 417) revealed 17 genes and 249 unique nucleotide sequences that were present only in strain 3004. Most of the unique genes related to phage sequences and genes type IV secretion systems. The functional annotation of unique genes revealed the fact of their high homology $(98 \%, 93 \%$, and $93 \%)$ with the genes of the species $X$. campestris, $X$. hortorum, $X$. gardneri. According to the comparison results, only phage sequences are truly unique (present exclusively in the genome of strain 3004). With functional annotation of 249 unique 
nucleotide sequences, the fact of the high homology of most of them with species $X$. campestris, $X$. hortorum and $X$. gardneri was also revealed. Truly unique are a number of genes belonging to the classes of tyrosine hydroxylases, M4 peptidases, MarR family transcription regulators, histidine kinases, NAD-malic enzymes, MutT proteins, esterases, thioridoxins, MFS transporters, and genes with unknown function. Multiple alignment using the Progressive mauve algorithm also revealed the proximity of many DNA fragments to other species of xanthomonads, and not to previously published genomes of $X$. arboricola strains. The abovementioned facts may be a sign of mosaic genome. Mosaic genome, in turn, may indicate that $X$. arboricola str. 3004 is closer to the last common ancestor of the genus Xanthomonas bacteria than representatives of the specialized pathovariants of $X$. arboricola.

\subsection{Discussion}

Ability to cause the disease is associated with the presence of pathogenicity genes. A typical bacterial genome of the genus Xanthomonas encodes about 4,000 genes. Pathogenicity genes are usually found in clusters or operons: xps - encoding a type II secretion system (T2SS); rpf - regulatory synthesis of pathogenicity factors; hrp - encoding T3SS; gum - responsible for the synthesis of xanthan polysaccharide; T4SS genes [19-20]. Differences between Xanthomonas spp. in the composition of genes that encode enzymes for degradation of the plant cell wall, may be associated with a difference in the cell wall composition among the corresponding host plants, as well as with differences in the symptoms. But the presence of these genes in both pathogenic and non-pathogenic strains does not indicate their key role in pathogenesis. T3SS genes are found in most species of Xanthomonas. The sets of T3E genes are very diverse [21], and are associated with the process of adaptation to the host response to infection. The secretion system of type IV in Xanthomonas bacteria is not fully understood. T4SS carries effectors with bacteriolytic activity and the ability to degrade peptidoglycan in target cells [18]. The virB + virD4 gene complex is found in many species of xanthomonads, regardless of their pathogenic activity [19-20].

Most authors believe that the presence of a type III secretion system determines the strain's pathogenicity. When studying the set of T3SS and T3E genes in the species $X$. arboricola, it was shown that they are necessary for virulence [22]. Acquisition of T3SS allows previously avirulent strains to suppress the hypersensitive response-like necrosis [23]. Non-pathogenic strains either do not contain T3SS genes or contain only a limited number of them [24-29]. Epiphytic bacteria $X$. campestris contain only the $h r p G$ and $h r p X$ genes. It is possible that these genes are induced to regulate plant cell wall degradation genes, which allows the epiphyte to receive nutrients [9].

Results of our studies show that it is not necessary to acquire the T3SS and T3E genes for the appearance of pathogenicity. According to genomic analysis, X. arboricola str. 3004 should belong to epiphytic strains, since it does not have T3SS genes and associated T3E genes. However, $X$. arboricola str. 3004-like strains isolated in the Russian Federation are pathogenic in a wide range of plants. As a factor contributing to the acquisition of pathogenic properties is the probable horizontal gene transfer of the VirE protein (COG5545) from Xylella fastidiosa using the Xantho Xp10 phage.

\section{Conclusion}

It is still not completely clear what role epiphytic strains play in the evolution and pathogenesis of Xanthomonas spp. All theories about evolution of the genus Xanthomonas bacteria can be divided into two groups: (1) pathogenic strains evolved from non-pathogenic ones by acquiring virulence genes; (2) non-pathogenic strains evolved from pathogens by the loss of virulence genes. 
The fact that the loss of a cluster of pathogenicity genes could be the initial event of evolution is considered by the example of Pseudomonas spp. in a study of Mohr et al. [29]. Meline et al. [23] also noted that acquiring T3SS genes may reduce the ability of $X$. campestris strains to survive on a plant [23]. This fact may explain the loss of virulence genes assumed by Merda et al. [24].

We support the hypothesis that it is epiphytic strains that are the ancestral form, and horizontal virulence gene transfer is the main driving factor of evolution. This hypothesis is supported by the results obtained in the analysis of the genome of $X$. arboricola str. 3004. It affects a wide range of host plants: barley, wheat, rapeseed, cabbage, tomato, walnut and sunflower. Genome $X$. arboricola str. 3004 has a mosaic structure, i.e. has many genes that are closer to other species of the genus Xanthomonas, which may indicate the relative proximity of this group of bacteria to the last mutual ancestor of xanthomonads. We suggest that the strain could be an epiphyte until the virE gene was obtained as a result of the horizontal gene transfer. In addition, we believe that acquisition of T3SS, described by Meline et al. [23], is not the only prerequisite for pathogenicity. Close attention should be paid to studying the role of T4SS in the pathogenesis of Xanthomonas. It was shown by using the symbiotic species Mesorhizobium loti as an example that type IV and type III secretion systems can be used interchangeably [30]. It is possible that T3SS plays a role only in the specialization of strains that is acquired by the mechanism described by Monteil et al. for bacteria of the genus Pseudomonas [31].

\section{References}

1. J. Swings, L. Civetta, Xanthomonas (Springer Science \& Business Media, Luxembourg, 2012)

2. J. L. Maas, M. M. Finney, E. L. Civerolo, M. Sasser, Phytopathology 75, 438 (1985)

3. A. M. Alvarez, A. A. Benedict, C. Y. Mizumoto, Phytopathology 75, 722 (1985). DOI: 10.1094/Phyto-75-722

4. R. L. Gilbertson, R. E. Rand, D. J. Hagedorn, Plant Dis 74, 322 (1990)

5. R. D. Gitaitis, M. J. Sasser, R. W. Beaver, T. B. Mclnnes, R. E. Stall, Phytopathology 77, 611 (1986). DOI: 10.1094/Phyto-77-611

6. D. Ming, H. Ye, N. W. Schaad, D. A. Roth, Phytopathology 81, 1358 (1991)

7. J. Garita-Cambronero, A. Palacio-Bielsa, M. M. López, J. Cubero, Front microbial 8, (2017). DOI: 10.3389/fmicb.2017.00573

8. L. Vauterin, P. Yang, A. Alvarez, Y. Takikawa, D. A. Roth, A. K. Vidaver, R. E. Stall, K. Kersters, J. Swings, Syst. Appl. Microbiol 19, 96 (1996)

9. Y. A. Lee, P. Y Yang, S. C. Huang, Phytopathology 110, (2020)

10. N. V. Punina, Ocenka geneticheskogo raznoobraziya fitopatogennyh bakterij roda Xanthomonas i razrabotka molekulyarnyh markerov dlya ih diagnostiki [Evaluation of the genetic diversity of phytopathogenic bacteria of the genus Xanthomonas and developing molecular markers for their diagnostics] (Moscow, 2009)

11. A. Hajri, J. F. Pothier, M. Fischer-Le Saux, S. Bonneau, S. Poussier, T. Boureau, B. Duffy, C. Manceau, Appl Environ Microbiol 78, 371(2012). DOI: 10.1128/AEM.0611911

12. M. V. Mokryakov, I. A. Abdeev, E. S. Piruzyan, N. W. Schaad, A. N. Ignatov, Microbiol. 79, 58 (2010). DOI: 10.1134/S002626171001008X

13. J. M. Young, D. C. Park, H. M. Shearman, E. Fargierc, Syst Appl Microbiol. 31, 366 (2008). DOI: 10.1016/j.syapm.2008.06.004 
14. M. S. Egorova, A. N. Ignatov, E. S. Mazurin, RUDN Journal of Agronomy and Animal Industries 15 (2014)

15. A. N. Ignatov, E. I. Kyrova, S. V. Vinogradova, A. M. Kamionskaya, N. W. Schaad, D. G. Luster, Genome Announc 3, (2015). DOI: 10.1128/genomeA.01572-14

16. T. Brettin, J. J. Davis, T. Disz, R. A. Edwards, S. Gerdes, G. J. Olsen, R. Olson, R. Overbeek, B. Parrello, G. D. Pusch, M. Shukla, J. A. Thomason, R. Stevens, V. Vonstein, A. R. Wattam, F. Xia, Scientific Reports 5 (2015). DOI: 10.1038/srep08365

17. A. E. Darling, B. Mau, N. T. Perna, PLoS ONE 5 (2010). DOI: 10.1371/journal.pone.0011147

18. D. P. Souza, G. U. Oka, C. E. Alvarez-Martinez, A. W. Bisson-Filho, G. Dunger, L. Hobeika, N. S. Cavalcante, M. C. Alegria, L. R. S. Barbosa, R. K. Salinas, C. R. Guzzo, C. S. Farah, Nat. Commun. 6 (2015). DOI: 10.1038/ncomms7453

19. P. J. Christie, Biochim. Biophys. Acta. 1694, 219 (2004). DOI: 10.1016/j.bbamcr.2004.02.013

20. R. P. Ryan, F. J. Vorhölter, N. Potnis, J. B. Jones, M. A. Van Sluys, A. J. Bogdanove, J. M. Dow, Nat. Rev. Microbiol. 9, 344 (2011). DOI: 10.1038/nrmicro2558

21. H. C. McCann, D. S. Guttman, New Phytol. 177, 33 (2008). DOI: 10.1111/j.14698137.2007.02293.x

22. A. Hajri, C. Brin, G. Hunault, F. Lardeux, C. Lemaire, C. Manceau, T. Boureau, S. Poussier, PLoS ONE 4 (2009). DOI: 10.1371/journal.pone.0006632

23. V. Meline, W. Delage, C. Brin, C. Li-Marchetti, D. Sochard, M. Arlat, C. Rousseau, A. Darrasse, M. Briand, G. Lebreton, P. Portier, M. Fischer-Le Saux, K. Durand, M. Jacques, E. Belin, T. Boureau, Mol. Plant Pathol. 20, 33 (2019)

24. D. Merda, M Briand, E. Bosis, C. Rousseau, P. Portier, M. Barret, M.-A. Jacques, M. Fischer-Le Saux, Mol. Ecol. 26, 5939 (2017). DOI: 10.1111/mec.14343

25. D. Merda, S. Bonneau, J.-F. Guimbaud, K. Durand, C. Brin, T. Boureau, C. Lemaire, M.-A. Jacques, M. Fischer-Le Saux, Environ. Microbiol. 8, 572 (2016). DOI: 10.1111/1758-2229.12397

26. J. Garita-Cambronero, A. Palacio-Bielsa, M. M. López, J. Cubero, PLoS One 11 (2016). DOI: 10.1371/journal.pone.0161977

27. S. Cesbron, M. Briand, S. Essakhi, S. Gironde, T. Boureau, C. Manceau, M. Fischer-Le Saux, M.-A. Jacques, Front. Plant Sci. 6 (2015). DOI: 10.3389/fpls.2015.01126

28. S. Essakhi, S. Cesbron, M. Fischer-Le Saux, S. Bonneau, M.-A. Jacques, C. Manceau, Appl. Environ. Microbiol. 81, 5395 (2015). DOI: 10.1128/AEM.00835-15

29. T. J. Mohr, H. Liu, S. Yan, C. E. Morris, J. A. Castillo, J. Jelenska, B. A. Vinatzer, J Bacteriol. 190, 2858 (2008). DOI: 10.1128/JB.01757-07

30. A. Hubber, A. C. Vergunst, J. T. Sullivan, P. J. Hooykaas, C. W. Ronson, Mol. Microbiol. 54, 561 (2004). DOI: 10.1111/j.1365-2958.2004.04292.x

31. C. L. Monteil, R. Cai, H. Liu, E. Marco, M. Llontop, S. Leman, D. J. Studholme, C. E. Morris, B. A. Vinatzer, New phytol. 199, 800 (2013). DOI: 10.1111/nph.12316 